\title{
Studi Deskriptif Pembelajaran Tematik Dalam Membaca Dan Menulis Permulaan Dengan Menggunakan Metode Struktural Analitik Sentesis (SAS)
}

\author{
Sabar Satriawan \\ Program Magister Pendidikan Dasar Universitas Bengkulu \\ sabarsatriawan888@gmail.com \\ Daimun Hambali \\ Program Magister Pendidikan Dasar Universitas Bengkulu \\ Abdul muktadir \\ Program Magister Pendidikan Dasar Universitas Bengkulu
}

\begin{abstract}
Penelitian ini bertujuan untuk mendeskripsikan perencanaan, pelaksanaan, evaluasi pembelajaran tematik dalam membaca dan menulis permulaan dengan menggunakan metode struktural analitik sentesis (SAS) di SD Negeri 29 Kaur. Jenis penelitian yang digunakan adalah deskriptif kualitatif. Subjek penelitian adalah guru dan siswa kelas I SD Negeri 29 Kaur. Guru I orang dan siswanya 15 siswa. Instrumen Penelitian lembar observasi, wawancara, dokumentasi. Teknik pengumpulan dan perekaman data mengunakan wawancara, observasi, dokumentasi dengan uji kreadibilitas data dan melalui perpanjangan pengamatan, meningkatkan ketekunan, triangulasi. Data yang telah diperoleh dianalisis melalui reduksi data, dan penarikan kesimpulan. Hasil penelitian ini mendiskripsikan pembelajaran membaca dan menulis permulaan dengan menggunakan metode SAS bahwa guru telah menerapkan komponen pembelajaran yang mencakup perencanaan yaitu silabus dan RPP, pelaksanaan kegiatan pembuka, inti, dan penutup, dan evaluasi pembelajarn membaca dan menulis permulaan di kelas I SD Negeri 29 Kaur.
\end{abstract}

Kata Kunci : Membaca, Menulis, SAS

\section{Pendahuluan}

Berdasarkan observasi yang telah dilakukan di SDN 29 Kaur. Peneliti menemukan beberapa siswa kelas I yang mengalami masalah dalam belajar membaca dan menulis permulaan. Hal itu nampak pada tulisan siswa yang semerawut, yaitu hasil tulisan yang tidak rapi, tidak menggunakan sepasi, tulisan naik turun tidak sesuai dengan garis buku, 
siswa menggabungkan huruf kapital dan huruf kecil sehingga tulisan siswa sulit dibaca. Hal itu sesuai dengan pendapat (Kurniastuti 2014 : 173) Bahwa setiap anak yang mengalami ketidak lancaran membaca di kelas awal umumnya akan mengalami kesulitan yang sama di kelas selanjutnya dan berdampak kegagalan di area akademik lainnya.

Pembelajaran membaca dan menulis permulaan (MMP) merupakan program pembelajaran yang diorientasikan kepada kemampuan membaca dan menulis permulaan di kelas-kelas awal pada saat peserta didik mulai memasuki bangku sekolah. Pada tahap awal peserta didik memasuki bangku sekolah di kelas 1 sekolah dasar, pembelajaran membaca dan menulis permulaan (MMP) merupakan program pembelajaran utama (Mulyati, 2014: 6 dan Kemendikbud, 2012).

Mengapa disebut permulaan dan apa sasarannya. Peralihan dari masa bermain di TK/RA (bagi yang mengalaminya) atau dari lingkungan rumah (bagi yang tidak menjalani masa di TK/RA) ke dunia sekolah merupakan hal baru bagi peserta didik. Hal pertama yang diajarkan kepada peserta didik pada awal- awal masa persekolahan itu adalah kemampuan membaca dan menulis. Kedua kemampuan ini akan menjadi landasan dasar bagi pemerolehan bidang-bidang ilmu lainnya di sekolah atau madrasah.

Kurikulum 2013 merupakan kurikulum terkini yang digunakan di sekolah-sekolah sebagai pengganti kurikulum sebelumnya, yakni Kurikulum tingkat satuan pendidikan (KTSP) tahun 2006. Penyempurnaan kurikulum ini mengacu pada Undang-undang No. 20 Tahun 2003 tentang Sistem Pendidikan Nasional dan Peraturan Pemerintah No. 58 Tahun 2014 terkait perubahan standar nasional pendidikan. Standar-standar dimaksud berkenaan dengan standar isi, proses, standar kompetensi lulusan, dan standar penilaian, serta penetapan kerangka dasar dan standar kurikulum yang ditentukan oleh BNSP.

Seperti dijelaskan dalam Kurikulum 2013, bahwa kompetensi inti setiap mata pelajaran pada pendidikan dasar dan menengah, ada empat yaitu: kompetensi sikap spritual, kompetensi sikap sosial, kompetensi pengetahuan, dan kompetensi keterampilan. Kompetensi tersebut diajarkan secara terintegrasi pada setiap materi dan mata pelajaran. Demikian pula pada pelajaran Bahasa dan Sastra Indonesia.

Upaya penyempurnaan kurikulum dimaksudkan untuk mewujudkan peningkatan mutu dan relevansi pendidikan dengan kebutuhan masyarakat yang harus dilakukan secara menyeluruh mencakup pengembangan dimensi manusia Indonesia seutuhnya. Dimensi-dimensi dimaksud meliputi aspek-aspek moral, akhlak, budi pekerti, pengetahuan, keterampilan, kesehatan, seni, dan budaya. Pengembangan aspek-aspek tersebut bermuara pada peningkatan dan pengembangan kecakapan hidup yang diwujudkan melalui pencapaian kompetensi peserta didik untuk bertahan hidup serta menyesuaikan diri, dan berhasil dalam kehidupannya.

Kurikulum tersebut dikembangkan secara lebih lanjut sesuai dengan kebutuhan dan keadaan masing-masing sekolah setempat. Kompetensi inti dan kompetensi dasar mata pelajaran Bahasa Indonesia hendaknya memadai dan efektif sebagai alat berkomunikasi, berinteraksi sosial, media pengembangan ilmu, dan alat pemersatu bangsa. Daerah atau sekolah-sekolah diberi kesempatan untuk menjabarkan kompetensi itu sesuai dengan kebutuhan dan keadaan masing-masing secara kontekstual.

Kompetensi dasar mata pelajaran Bahasa Indonesia, khususnya aspek membaca, untuk SD dan MI diadaptasi dari standar kompetensi kurikulum sebelumnya adalah sebagai berikut: "Membaca huruf, suku kata, kata, kalimat, paragraf, berbagai teks bacaan, denah, petunjuk, tata tertib, pengumuman, kamus, ensiklopedia, serta mengapresiasi dan berekspresi sastra melalui kegiatan membaca hasil sastra berupa dongeng, cerita anakanak, cerita rakyat, cerita binatang, puisi anak, syair lagu, pantun, dan drama anak. Kompetensi membaca juga diarahkan menumbuhkan budaya baca.

Kompetensi aspek membaca di kelas rendah sekolah dasar/madrasah ibtidaiyah ialah siswa mampu membaca dan memahami teks pendek dengan cara membaca lancar (bersuara) dan membaca nyaring beberapa kalimat sederhana.

Kompetensi ini diturunkan ke dalam empat buah kom petensi dasar, yakni: 1) 
membiasakan sikap membaca yang benar, 2) membaca nyaring, 3) membaca bersuara (lancar), 4) membacakan penggalan cerita.

Untuk kompetensi menulis di kelas rendah, kurikulum sebelumnya diadaptasi pada Kurikulum 2013 menetapkan kompetensi sebagai berikut: Siswa mampu menulis beberapa kalimat yang dibuat sendiri dengan huruf lepas dan huruf sambung, menulis kalimat yang diiktekan guru, dan menulis rapi menggunakan huruf sambung.

Standar kompetensi ini diturunkan ke dalam tujuh buah kompetensi dasar, yakni: 1) membiasakan sikap menulis yang benar (memegang dan menggunakan alat tulis), 2) menjiplak dan menebalkan, 3) menyalin, 4) menulis permulaan, 5) menulis beberapa kalimat dengan huruf sambung, 6) menulis kalimat yang didiktekan guru, dan 7) menulis dengan huruf sambung.

Kedua kompetensi tersebut yakni membaca dan menulis diajarkan secara terpadu dengan kompetensi menyimak dan berbicara yang dilingkupi tema dan sub tema dalam setiap pembelajaran dengan memadukan berbagai mata pelajaran.

Metode pembelajarn MMP dapat mengajarkan membaca dan menulis permulaan seperti dikutip dari (Mulyati, 2014: 15-23 \& Kemendikbud, 2012: 8-15), ada beberapa metode yang dapat dijadikan acuan untuk mengajarkannya MMP yaitu metode SAS.

Metode SAS struktural analitik sintetik atau yang biasa disingkat dengan SAS merupakan salah satu metode yang dapat digunakan dalam pembelajaran membaca dan menulis permulaan. Pembelajaran MMP dengan metode ini mengawali pelajarannya dengan menampilkan dan memperkenalkan sebuah kalimat utuh. Mula-mula anak disuguhi sebuah struktur yang memberi makna lengkap, yakni struktur kalimat. Hal ini dimaksudkan untuk membangun konsep-konsep "kebermaknaan" pada diri anak. Akan lebih baik jika struktur kalimat yang disajikan sebagai bahan pembelajaran MMP dengan metode ini adalah struktur kalimat yang digali dari pengalaman berbahasa si pebelajar itu sendiri.

Untukitu, sebelum pembelajaran MMP dimulai, guru dapat melakukan prapembelajaran melalui berbagai cara. Sebagai contoh, guru dapat memanfaatkan rangsang gambar, benda nyata, tanya jawab informal untuk menggali bahasa peserta didik. Setelah ditemukan suatu struktur kalimat yang dianggap cocok untuk materi MMP, barulah pembelajaran MMP yang sesungguhnya dimulai. Pembelajaran MMP dimulai dengan pengenalan struktur kalimat. Kemudian, melalui proses analitik, peserta didik diajak untuk mengenal konsep kata. Kalimat utuh yang dijadikan tonggak dasar untuk pembelajaran membaca permulaan ini diuraikan ke dalam satuan-satuan bahasa yang lebih kecil yang disebut kata.

Proses penganalisisan atau penguraian ini terus berlanjut hingga pada wujud satuan bahasa terkecil yang tidak bisa diuraikan lagi, yakni huruf-huruf.

Proses penguraian/penganalisian dalam pembelajaran MMP dengan metode SAS meliputi:

1. Kalimat menjadi kata-kata

2. Kalimat menjadi suku kata, dan

3. Suku kata menjadi huruf-huruf

Pembelajaran MMP terdiriatas pembelajaran membaca permulaan dan pembelajaran menulis permulaan. Pembelajaran membaca permulaan terbagi ke dalam dua tahap, yakni: pembelajaran membaca tanpa buku dan pembelajaran membaca dengan menggunakan buku.

Terdapat bermacam variasi pembelajaran membaca permulaan, di antaranya membaca buku pelajaran (buku paket), membaca buku/majalah anak, membaca bacaan susunan bersama guru-siswa, membaca bacaan hasil susunan siswa. Sedangkan pembelajaran menulis permulaan terbagi ke dalam dua tahap, yakni tahap pengenalan huruf dan pelatihan menulis. Variasi bentuk latihan menulis permulaan, di antaranya latihan pramenulis (memegang pensil dan gerakan tangan), menghubungkan tanda titiktitik, menyalin, menulis halus/indah, dikte/imla, melengkapi tulisan, dan mengarang sederhana. 


\section{Metode}

Penelitian ini menggunakan metode penelitian deskriptif dengan menggunakan pendekatan kualitatif. Pemilihan metode ini didasarkan pertimbangan-pertimbangan bahwa data yang dikumpulkan dari SD Negeri 29 Kaur adalah yang apa adanya tanpa mencari hubungan yang terlalu mendalam. Menurut Sedarmayanti (2011: 22) penelitian kualitatif adalah penelitian yang dilakukan pada kondisi obyek yang alami, peneliti sebagai instrumen kunci, teknik pengumpulan data dilakukan secara gabungan, data yang dihasilkan bersifat deskriptif dan analisis data dilakukan secara induktif dan penelitian ini lebih menekankan makna dari pada generalisasi.

Menurut Mukhtar (2013: 4) mengemukakan bahwa penelitian kualitatif banyak dikembangkan dalam penelitian sosial, budaya, agama, pendidikan, pisikologi, komunikasi dan sebagainya. “. Sebagaimana yang dikatakan Bailey (1982) dalam Mukhtar (2013: 11),

"Penelitian kualitatif deskriptif selain mendiskusikan berbagai kasus yang sifatnya umum tentang berbagai fenomena sosial yang ditemukan, juga harus mendiskripsikan hal-hal yang besifat spesifik yang dicermati dari sudut kemengapaan dan kebagaimanaan terhaap suatu realitas yang terjadi baik perilaku yang ditemukan dipermukaan lapisan sosial, juga yang tersembunyi dibalik sebuah perilaku yang ditunjukkan".

Berkaitan deskriftif, Winarni, (2011: 38) mengemukakan bahwa "penelitian deskriptif adalah penelitian yang diarahkan untuk memberikan gejala-gejala, fakta- fakta, kejadiankejadian serta sistematis dan akurat, mengenai sifat- sifat populasi atau daerah tertentu".

Sebagaimana telah dikemukakan di atas, penelitian ini tidak bermaksud mengemukakan hubungan antar variabel melalui studi korelasi atau regresi untuk menguji hipotesa tertentu. Sehingga penelitian ini menuntut peneliti untuk melakukan eksplorasi dalam rangka memahami dengan menjelaskan masalah yang diteliti melalui komunikasi yang intensif dengan sumber data. Dalam proses penelitian ini, peneliti dibimbing oleh suatu "conceptual framework", dimana peneliti harus mempunyai tingkat intensitas pemahaman terhadap suatu konsepsi atau teori. Konsepsi ini merupakan persepsi teoritis yang dijadikan pedoman proses inquiri oleh peneliti. Hal inidimaksudkan agar apa yang dihasilkan penelitian ini tidak hanya merupakan kumpulan dataatau informasi saja, tetapi merupakan informasi yang tersusun secara terarah dan terorganisasi dalam suatu struktur pemikiran tetentu sehingga mempunyai makna untuk menjelaskan masalah yang diteliti.

Data yang dikumpulkan dalam penelitian ini biasanya disebut lunak, artinya, kaya dalam pengutaraan tentang orang, tempat, dan percakapan, dan tidak gampang digarap dengan menggunakan prosedur statistik. Data yang terkumpul berupa uraian yang kaya akan deskripsi mengenai kegiatan subyek yang diteliti, pendapatnya dan aspek-aspek lainnya yang berkaitan sebagai hasil yang diperoleh melalui wawancara, observasi dan studi dokumenter.

Dalam penelitian kualitatif, pertanyaan penelitian tidak dirumuskan atau dasar operasional dari suatu variabel penelitian. Pertanyaan penelitian kualitatif dirumuskan dengan maksud untuk memahami gejala yang kompleks dalam kaitannya dengan aspekaspek lain. Peneliti yang menggunakan pendekatan kualitatif, pada tahap awal penelitiannya kemungkinan belum memiliki gambaran yang jelas tentang aspek-aspek masalah yang akan ditelitinya.

Peneliti biasanya mengembangkan focus penelitiannya sambil ia mengumpulkan data. Penelitian kualitatif tidak menghampiri masalah yang ditelitinya melalui pertanyaan penelitian yang telah dirumuskan sebelumnya untuk dicarikan jawabannya atau melalui perumusan hipotesis untuk dibuktikan kebenarannya. Ciri lainnya dari penelitian kualitatif ini adalah "Observasi partisipan dan wawancara mendalam". Peneliti memasuki dunia manusia yang ingin dipelajarinya, berkenalan, dikenal dan dipercaya mereka, dan secara sistematis membuat catatan rinci tentang apa- apa yang didengar dan diamatinya. 
Di bidang pendidikan penelitian kualitatif seringkali disebut " naturalistik", sebab peneliti tertarik untuk menyelidiki peristiwa-peristiwa sebagaimana terjadi secara natural (alamiah). Dan datanya dikumpulkan oleh orang-orang yang berperilaku secara wajar, berbicara, berkunjung, memandang, makan dan sebagainya (Bogdan dan baiklen 2005: 3).

Dengan karakteristik pertama, peneliti sendiri mendatangi langsung sumber datanya. Peneliti masuk ke sekolah, rumah (keluarga), lingkungan tetangga dan tempat lainnya dan cukup lama di situ untuk mempelajari masalah- masalah pendidikan. Adakalanya beberapa peneliti menggunakan alat perlengkapan kamera, walaupun ada juga datang ke lokasi penelitian dengan tanpa alat-alat selain buku catatan dan perlengkapan lainnya.

Karakteristik kedua, mengimplikasikan bahwa data yang dikumpulkan biasanya berbentuk kata-kata atau gambar daripada angka-angka. Data itu biasanya meliputi transkrip wawancara, catatan lapangan, foto, dan catatan- catatan resmi lainnya. Tulisan dan laporan hasil penelitian sebagai hasil analisisnya berupa suatu uraian. Dengan kata lain dapat dikatakan bahwa laporan hasil penelitian kualitatif biasanya diungkapkan dalam bentuk kata-kata, jadi lebih banyak berupa deskripsi dan penjelasan-penjelasan tentang aspek- aspek masalah yang menjadi fokus penelitian.

Karakteristik ketiga, menjelaskan bahwa penelitian kualitatif lebih menaruh perhatian dan lebih menekankan kepada proses dan tidak semata-mata kepada kepada hasil yang diperoleh. Karakteristik keempat, menekankan bahwa periset kualitatif cenderung menganalisis datanya secara induktif, sedangkan karakteristik kelima, lebih menekankan bahwa makna merupakan hal yang esensial untuk rencangan kualitatif.

\section{Hasil}

Berdasarkan hasil dan temuan dengan menggunakan metode observasi, wawancara dan dokumentasi, dapat diuraikan sebagai berikut.

\section{Deskripsi hasil tentang perencanaan pembelajaran membaca dan menulis permulaan dengan metode struktural analitik sentesis (SAS) pada mata pelajaran Tematik kelas I di SD Negeri 29 Kaur}

Perencanaan pembelajaran pada hakikatnya disusun dalam rangka melaksanakan proses pembelajaran. Perencanaan pembelajaran adalah suatu proses penentu rencana program kegiatan yang akan dilakukan secara terpadu dan sistematis. Perencanaan pembelajaran merupakan tugas pokok yang harus dilakukan oleh seorang guru sebelum melaksanakan kegiatan pembelajaran.

a. Silabus

Berdasarkan rumusan masalah pertama tentang perencanaan pembelajaran membaca dan menulis permulaan pada mata pelajaran Tematik kelas I di SD Negeri 29 Kaur pada tahap perencanaan berdasarkan dokumentasi guru sudah membuat silabus dengan kelengkapan komponennya mengacu pada standar proses, yaitu identitas silabus, kompetensi dasar, indikator, kegiatan pembelajaran, penilaian proses dan hasil belajar, alokasi waktu, sumber dan media. Berdasarkan jawaban pada saat wawancara guru membuat silabus berdasarkan kurikulum yang berlaku yaitu kurikulum K13. Berdasarkan dokumentasi guru membuat identitas silabus mulai dari nama sekolah, mata pelajaran, kelas, semester.

b. RPP

Berdasarkan dokumentasi guru dalam merancang RPP sudah memuat komponenkomponen RPP yaitu identitas RPP, standar kompetensi, kompetensi dasar, tujuan pembelajaran, materi pembelajaran, metode pembelajaran, langkah- langkah pembelajaran, alat dan bahan serta penilaian. Dalam membuat identitas berdasarkan dokumentasi, guru sudah membuat identitas RPP. Guru membuat identitas mulai dari nama sekolah, mata pelajaran, kelas, dan alokasi waktu. Berdasarkan jawaban guru pada saat wawancara mengatakan bahwa guru membuat identitas RPP 
berdasarkan muatan kurikulum. Selanjutnya guru sudah menetapkan. Kompetensi dasar yang yang ditetapkan guru yaitu KD 3.1 Mengenal kegiatan persiapan membaca permulaan (cara duduk wajar dan baik, jarak antara mata dan buku, gerakan mata dari kiri ke kanan, memilih tempat dengan cahaya terang) dengan cara yang benar. 4.1 Mempraktikkan kegiatan persiapan membaca permulaan (duduk wajar dan baik, jarak antara mata dan buku, cara memegang buku, cara membalik halaman buku, gerakan mata dari kiri ke kanan, memilih tempat dengan cahaya terang) dengan cara yang benar.

Dalam membuat indikator, guru mengembangkan indikator membaca dan menulis permulaan dengan tema yang lebih luas. Hal ini dikatakan guru pada saat wawancara bahwa RPP dikembangkan sesuai dengan kebutuhan siswa. Pada tujuan pembelajaran, berdasarkan dokumentasi peneliti, guru sudah merumuskan tujuan pembelajaran yaitu Dengan mengamati gambar dan mendengarkan penjelasan guru, siswa dapat mengidentifikasi dan mendemonstrasikan cara memegang dan membalik buku serta membaca dengan pencahayaan yang benar. Materi pembelajaran yang ada pada RPP yaitu persiapan mengenal huruf untuk membaca dan menulis permulaan. Berdasarkan hasil wawancara, guru menetapkan materi sesuai dengan kurikulum dengan mempertimbangkan kemampuan siswa.

Dalam menentukan metode pembelajaran, berdasarkan dokumentasi guru menggunakan metode struktural analitik sentesis (SAS) apersepsi, demonstrasi dan penugasan. Berdasarkan jawaban guru pada saat wawancara mengatakan bahwa metode pembelajaran yang dipilih beracuan pada tujuan pembelajaran yang akan dicapai dan situasi dalam kelas. Selanjutnya dalam merencanakan kegiatan pembelajaran yang efektif pada pembelajaran membaca dan menulis permulaan, berdasarkan jawaban guru pada saat wawancara mengatakan bahwa, untuk merencanakan kegiatan pembelajaran yang efektif saya berpedoman pada RPP yang telah dibuat dengan sebelumnya menyesuaikan alokasi waktunya dan kemampuan siswa demi tercapainya tujuan pembelajaran yang bermakna. Dalam menyusun langkah pembelajaran berdasarkan dokumentasi guru menyusun langkah pembelajaran mulai dari kegiatan pendahuluan, kegiatan inti dan kegiatan penutup. Dalam kegiatan pendahuluan, guru membuka pembelajaran guru menyapa siswa, menanyakan kabar siswa, melakukan apersepsi serta menjelaskan rencana pembelajaran dan tujuan pembelajaran.

Kegiatan inti dengan menerapkan metode struktural analitik sentesis (SAS). Dalam kegiatan guru memfasilitasi terjadinya interaksi antar siswa serta antara siswa dengan guru, lingkungan dan sumber belajar lainnya. Melibatkan siswa secara aktif dalam setiap kegiatan pembelajaran. Dalam kegiatan ini guru bertanya jawab tentang hal-hal yang belum diketahui siswa, dan guru dan siswa bersama- sama meluruskan kesalah pahaman dan memberikan kesimpulan. Kegiatan penutup guru memberikan soal pekerjaan rumah dan menutup pelajaran. Berdasarkan dokumentasi guru menggunakan buku Buku Pedoman Guru Tema 1 Kelas 1 dan Buku Siswa Tema 1 Kelas 1 (Buku Tematik Terpadu Kurikulum 2017, Jakarta: Kementerian Pendidikan dan Kebudayaan, 2017) sebagai alat dan sumber belajar. Dalam memilih media pembelajaran berdasarkan jawaban guru pada saat wawancara mengatakan bahwa untuk memilih media dalam pembelajaran, guru memilih dan menggunakan media berupa gambar yang telah tersedia di kelas. Gambar dan objek lainnya. Disamping menggunakan gambar guru juga menggunakan lingkungan sekitar sebagai media. Dalam menjabarkan jenis penilaian, berdasarkan dokumentasi menunjukan guru melakukan penilaian berupa hasil lembar kerja siswa (LKS). Selanjutnya instrumen penilaian sudah jelas tercantum pada RPP. Berdasarkan jawaban guru pada saat wawancara mengatakan bahwa penilaian dikembangkan sesuai dengan materi yang diajarkan.

2. Deskripsi hasil tentang pelaksanaan pembelajaran membaca dan menulis permulaan dengan menggunakan metode struktural analitik sentesis (SAS) pada 
mata pelajaran tematik kelas I di SD Negeri 29 Kaur

Berdasarkan rumusan masalah kedua tentang pelaksanaan pembelajaran membaca dan menulis permulaan pada mata pelajaran Tematik kelas I di SD Negeri 29 Kaur yang dilaksanakan pada hari selasa tanggal 22 juli 2018 dapat dideskripsikan sebagai berikut.

a. Kegiatan Pendahuluan Berdasarkan pengamatan, proses pembelajaran diawali dengan salam yang diucapkan oleh guru pada saat masuk ke ruang kelas I. Siswa pun dengan serentak menjawab salam dari guru. Kemudian, guru mengkondisikan siswa agar siap belajar dengan meminta siswa untuk duduk.

Guru mengecek kehadiran siswa dengan menyebut nama mereka satu per satu sesuai dengan urutan yang ada di buku daftar hadir siswa. Siswa terlihat fokus pada awal kegiatan. Selanjutnya guru melakukan apersepsi dengan mengajukan pertanyaan-pertanyaan yang mengaitkan pengetahuan siswa sebelumnya tentang membaca dan menulis permulaan. Guru bertanya bertanya kepada siswa "apakah kalian sebelumnya sudah pernah membaca dan menulis ?", siswa dengan serentak menjawab "sudah buk", guru bertanya lagi pada siswa "apakah kalian sudah siap belajar membaca dan menulis hari ini?", siswa menjawab dengan antusias "siaaappp bu", selanjutnya guru menginstruksikan siswa "kalau begitu buka buku cetak dan siapkan peralatan kalian untuk belajar hari ini”.

Berdasarkan informasi pengamatan, alat dan bahan yang digunakan siswa dalam pembelajaran membaca dan menulis permulaan seperti pensil, penghapus dan buku. Seraya siswa mempersiapkan alat dan bahan untuk membaca dan menulis permulaan. Siswa dibimbing guru dalam proses kegiatan pembelajaran membaca dan menulis permulaan. Berdasarkan pengamatan, guru belum menyampaikan tujuan dari pembelajaran. Guru hanya menginformasikan kepada siswa bahwa pembelajaran yang akan dilaksanakan yaitu tentang membaca dan menulis permulaan.

Berdasarkan jawaban guru pada saat wawancara mengatakan bahwa guru melakukan kegiatan pendahuluan terlebih dahulu mengkondisikan kelas dengan menyapa siswa, mengecek kehadiran siswa dan mendisiplinkan siswa agar siap untuk belajar. Setelah siswa sudah siap guru melakukan apersepsi menggunakan gambar-gambar yang ada di dinding kelas untuk memancing pengetahuan awal siswa tentang materi apa yang akan dipelajari. Siswa diminta untuk mempersiapkan semua alat-alat yang digunakan untuk pembelajaran membaca dan menulis permulaan.

3. Deskripsi hasil tentang evaluasi pembelajaran membaca dan menulis permulaan dengan menggunakan metode struktural analitik sentesis (SAS) pada mata pelajaran tematik kelas I di SD Negeri 29 Kaur

Dalam melakukan evaluasi pembelajaran, berdasarkan dokumentasi menunjukan pada perencanaan guru membuat lembar penilaian pembelajaran membaca dan menulis permulaan dengan memuat ranah kognitif (pengetahuan), afektif (sikap) dan psikomotor (keterampilan). Pada perencanaan guru membuat format kriteria penilaian pengetahuan dengan aspek berupa pemahaman konsep tentang membaca dan menulis permulaan. Berdasarkan jawaban guru pada saat wawancara penilaian pengetahuan pada pembelajaran membaca dan menulis yaitu mencangkup aspek pemahaman siswa atas konsep dan materi membaca dan menulis permulaan yang nantinya terlihat pada hasil lembar kerja siswa.

Selanjutnya penilaian sikap, berdasarkan jawaban guru pada saat wawancara penilaian sikap yaitu penilaian yang dilakukan yang mencangkup aspek sikap dan tingkah laku siswa pada saat proses pembelajaran. Berdasarkan dokumentasi penilaian yang dilakukan untuk indikator pencapaian kompetensi pembelajaran membaca dan menulis permulaan yaitu: a.persiapan mengenal huruf untuk membaca dan menulis permulaan. 


\section{Pembahasan}

\section{Perencanaan pembelajaran membaca dan menulis permulaan metode struktural analitik sentesis (SAS) pembelajaran Tematik kelas I di SD Negeri 29 Kaur}

Perencanaan pembelajaran membaca dan menulis permulaan metode struktural analitik sentesis (SAS) dalam pembelajaran Tematik kelas I di SD Negeri 29 Kaur menyangkut penetapan tujuan, dan kompetensi inti, serta memperkirakan bagaimana cara mencapainya. Dalam pengambilan dan pembuatan keputusan tentang proses pembelajaran di SD, gurulah sebagai menajer dalam pembelajaran yang melakukan berbagai pilihan menuju tercapainya tujuan. Hal ini sesuai dengan Mulyasa (2009: 77), bahwa perencanaan merupakan fungsi sentral dari manajemen pembelajaran dan harus berorientasi ke masa depan. Di samping itu, guru dalam pembelajaran harus mampu mengambil keputusan yang tepat untuk mengelola berbagai sumber, baik itu sumber daya, sumber dana, maupun sumber belajar untuk membentuk kompetensi dasar dan mencapai tujuan pembelajaran.

Dalam penyusunan silabus, berdasarkan penelitian guru sudah membuat silabus dengan kelengkapan komponennya, yang mengacu pada standar proses, yaitu kompetensi dasar, indikator, kegiatan pembelajaran, penilaian proses dan hasil belajar, alokasi waktu, sumber dan media. Pada hasil pengamatan pada silabus guru belum secara rinci menjelaskan setiap komponen.

Identitas sekolah, meliputi nama satuan pendidikan atau nama sekolah dan kelas. Sumber belajar juga diharapkan bahwa untuk pelaksanaan pembelajaran untuk implementasi kurikulum 2013 dapat bervariasi misalnya dalam bentuk buku, media cetak (koran atau majalah) dan media elektronik atau multimedia, atau alam sekitar serta sumber-sumber belajar lain yang relevan. Seharusnya guru mengembangkan komponen silabus untuk memudahkan pelaksanaan pembelajaran dan dapat dipergunakan sebagai acuan dalam melaksanakan proses pembelajaran di kelas.

Hal ini sesuai dengan pendapat Mulyasa (2008: 190), pengembangan komponenkomponen tersebut merupakan kewenangan mutlak guru, termasuk pengembangan format silabus, dan penambahan komponen- komponen lain dalam silabus di luar komponen minimal. Semakin rinci silabus, semakin membantu memudahkan guru dalam menjabarkannya dalam rencana pelaksanaan pembelajaran.

\section{Pelaksanaan pembelajaran membaca dan menulis permulaan dengan metode struktural analitik sentesis pada pembelajaran Tematik kelas I di SD Negeri 29 Kaur}

Pelaksanaan sering juga disebut dengan implementasi. Tahap pelaksanaan adalah proses yang memberikan keputusan bahwa proses belajar mengajar telah memiliki sumber daya manusia dan sarana serta prasarana yang diperlukan sehingga dapat membentuk kompetensi dan mencapai tujuan yang diinginkan. Hal ini sesuai dengan pendapat Susanto (2014: 48), "Pelaksanaan pembelajaran merupakan kegiatan inti dari keseluruhan proses pembelajaran". Pada bagian ini guru berperan untuk menyampaikan pesan, materi dan informasi penting lainnya yang harus diterima oleh siswa. Jika proses pelaksanaan pembelajaran ini tidak berhasil dilaksannakan guru, maka secara otomatis hasil atau tujuan pembelajaran akan gagal.

Saat pelaksanaan pembelajaran guru melaksanakan tahap pendahuluan, inti dan penutup. Namun guru belum secara utuh melaksanakan komponen- komponen pada setiap tahap pelaksanaan. Sementara itu menurut Permendiknas No 41 Tahun 2007 tentang standar proses yang memuat komponen-komponen dalam pelaksanaan pembelajaran yaitu: kegiatan pendahuluan, inti dan penutup. Pendahuluan merupakan kegiatan awal dalam suatu pertemuan pembelajaran yang ditujukan untuk membangkitkan motivasi dan memfokuskan perhatian peserta didik untuk berpartisipasi aktif dalam proses pembelajaran.

Kegiatan inti merupakan proses pembelajaran untuk mencapai KD. Kegiatan pembelajaran dilakukan secara interaktif, inspiratif, menyenangkan, menantang, 
memotivasi peserta didik untuk berpartisipasi aktif, serta memberikan ruang yang cukup bagi prakarsa, kreativitas, dan kemandirian sesuai dengan bakat, minat, dan perkembangan fisik serta psikologis peserta didik. Penutup merupakan kegiatan yang dilakukan untuk mengakhiri aktivitas pembelajaran yang dapat dilakukan dalam bentuk rangkuman atau kesimpulan, penilaian dan refleksi, umpan balik, dan tindak lanjut.

Berdasarkan penelitian, proses pembelajaran diawali dengan salam yang diucapkan oleh guru pada saat masuk ke ruang kelas I. Siswa pun dengan serentak menjawab salam dari guru. Kemudian, guru mengkondisikan siswa agar siap belajar dengan meminta siswa untuk duduk.

Guru mengecek kehadiran siswa dengan menyebut nama mereka satu per satu sesuai dengan urutan yang ada di buku daftar hadir siswa. Siswa terlihat fokus pada awal kegiatan. Selanjutnya guru melakukan apersepsi dengan mengajukan pertanyaanpertanyaan yang mengaitkan pengetahuan siswa sebelumnya tentang membaca dan menulis. Hal ini sudah sejalan dengan pendapat Aqib (2010: 56), kegiatan apersepsi lebih menekankan untuk mengetahui sejauh mana kemampuan awal yang dimiliki siswa. Seorang guru perlu menghubungkan materi pelajaran yang telah dimiliki siswa dengan materi yang akan dipelajari siswa dan tidak mengenyampingkan pemberian motivasi belajar kepada siswa.

Berdasarkan penelitian guru sudah menyiapkan siswa secara psikis dan fisik untuk mengikuti proses pembelajaran yaitu dengan guru sudah bisa melaksanakannya dengan terlebih dahulu mengkondisikan kelas, menyapa siswa, mengecek kehadiran siswa dan mendisiplinkan siswa agar siap untuk belajar. Hal ini sudah sejalan dengan pendapat Susanto (2014: 49) satu hal yang paling utama dari perlunya membuka pelajaran ini ialah untuk memberi motivasi pada siswa, menarik perhatian siswa, serta meberikan acuan bagi siswa tentang maksud dan tujuan, batas- batas, serta kontekstualisasi dengan kehidupan sehari-hari siswa sesuai dengan jenjang pendidikannya.

\section{Evaluasi pembelajaran membaca dan menulis permulaan pada mata pelajaran Tematik kelas I di SD Negeri 29 Kaur}

Penilaian atau evaluasi dalam pembelajaran dimaksudkan untuk memperoleh informasi tentang perolehan belajar siswa secara menyeluruh, baik pengetahuan, konsep, nilai, maupun proses. Permendikbud nomor 4 tahun 2018 mengenai penilaian hasil belajar tersebut bertujuan untuk mengukur kemampuan dari peserta didik yang sudah mendapatkan pembekalan materi selama dia berada di bangku sekolah. Pembekalan atau pemberian materi yang sudah mereka terima, tentunya harus di ukur dengan cara Penilaian hasil belajar oleh pemerintan dan juga satuan pendidikan. Yang meliputi Ujian Nasional, Ujian Sekolah Berstandar Nasional, dan Ujian Sekolah/Madrasah/Pendidikan Kesetaraan.

Dengan tujuan agar mengetahui berapa banyak materi yang sudah diberikan oleh pendidik diserap oleh peserta didik. Karena materi yang sudah disusun oleh pemerintah sudah sangat baik, sudah mencakup semua aspek dalam kehidupan di masa yang akan datang. Suryosubroto (2009: 22) mengatakan bahwa, hal yang harus dilakukan dalam evaluasi pembelajaran adalah:

a. melaksanakan tes; b. mengolah hasil penilaian; c. melaporkan hasil penilaian; d. melaksanakan program remedial.

Permendikbud nomor 4 tahun 2018 mengenai penilaian hasil belajar merupakan hasil yang telah dicapai seseorang setelah melakukan proses untuk mendapatkan perubahan tingkah laku, kognitif, afektif, serta psikomotorik. Tingkah laku disebut sebagai hasil belajar jika memenuhi syarat bahwa belajar merupakan pencapaian tujuan belajar, hasil dari proses yang disadari, dan tingkah laku yang berfungsi efektif dalam kurun waktu tertentu dan fungsi operasional. Terdapat tiga ranah dalam hasil belajar, yaitu ranah kognitif, ranah afektif, dan ranah psikomotorik.

Ranah kognitif adalah hasil belajar yang berupa pengetahuan- pengetahuan atau kemampuan baru yang bersifat keilmuan. Ranah afektif merupakan hasil belajar yang berupa perubahan-perubahan perilaku sebagai akibat telah dilakukannya proses belajar. Sedangkan ranah psikomotorik adalah hasil belajar yang berupa ketrampilan-ketrampilan 
praktis oleh anggota badan. Di dalam meningkatkan mutu penilaian hasil belajar oleh satuan pendidikan dan pemerintah, serta untuk mendorong pencapaian standar kompetensi lulusan secara nasional perlu meningkatkan mutu ujian oleh satuan pendidikan dan pemerintah.

\section{Kesimpulan}

Berdasarkan hasil penelitian, kesimpulan yang dapat diambil dari pembelajaran membaca dan menulis permulaan pada mata pelajaran tematik kelas I SD Negeri 29 Kaur, adalah sebagai berikut:

1.Pada tahap perencanaan, dalam penyusunan silabus, guru sudah membuat silabus dengan kelengkapan komponennya mengacu pada standar proses, yaitu kompetensi dasar, indikator, kegiatan pembelajaran, penilaian proses dan hasil belajar, alokasi waktu, sumber dan media. Tetapi pada silabus guru belum secara rinci menjelaskan setiap komponen. Selanjutnya guru dalam merancang RPP sudah memuat komponenkomponen RPP yaitu identitas RPP,standar kompetensi, kompetensi dasar, tujuan pembelajaran, materi pembelajaran, metode pembelajaran, langkah- langkah pembelajaran, alat dan bahan serta penilaian. RPP yang dibuat oleh guru sudah mengacu pada Permendiknas No 41 Tahun 2007 tentang standar proses.

2.Pada tahap pelaksanaan, guru melaksanakan pembelajaran mulai dari tahap pendahuluan, inti dan penutup. Pada kegiatan pendahuluan guru sudah menyiapkan siswa secara psikis dan fisik untuk mengikuti proses pembelajaran yaitu dengan guru sudah bisa melaksanakannya dengan terlebih dahulu mengkondisikan kelas, menyapa siswa, mengecek kehadiran siswa dan mendisiplinkan siswa agar siap untuk belajar. Pada kegiatan inti guru menggunakan metode sas dalam menjelaskan materi pembelajaran dan metode penugasan untuk menugaskan siswa membaca dan menulis permulaan. Guru belum sepenuhnya menjelaskan tentang materi membaca dan menulis, karena guru hanya menjelaskan tema dan sub tema yaitu dengan menggunakan tema tubuhku,. meskipun guru belum maksimal dalam menjelaskan materi kepada siswa, namun siswa bisa memahami materi membaca dan menulis melalui buku cetak/buku siswa yang dimiliki masing-masing siswa. Pada kegiatan penutup guru dan siswa bersama-sama membuat kesimpulan pemelajaran membaca dan menulis permulaan yang telah dilakukan.

3.Pada tahap evaluasi, guru mengevaluasi pembelajaran membaca dan menulis permulaan menggunakan lks yang diberikan pada penugasan siswa mengerjakan lks yang diberikan Guru menilai yang dibuat siswa kelas I dengan nilai. Berdasarkan nilai tersebut siswa termasuk kedalam kriteria nilai baik. Selain penilaian yang berorientasi pada hasil, guru juga menggunakan bentuk penilaian yang berorientasi pada proses. Guru menilai siswa seketika siswa melaksanakan kegiatan membaca dan menulis, penilaian ini bertujuan untuk memberi tahu dan membantu siswa yang mengalami kesulitan dalam membaca dan menulis permulaan, dan juga guru sudah melaksanakan penilaian sikap pada siswa, yang sebagaimana sudah tertera sebelumnya pada perencanaan pembelajaran.

\section{Saran}

1.Untuk perencanaan sebaiknya guru mengembangkan dan merincikan setiap komponen yang ada pada RPP dan Silabus. Pengembangan itu merupakan kewenangan mutlak guru, termasuk pengembangan format silabus, dan penambahan komponen-komponen lain dalam silabus di luar komponen minimal. Semakin rinci silabus, semakin membantu memudahkan guru dalam menjabarkannya dalam rencana pelaksanaan pembelajaran.

2.Dalam tahap pelaksanaan hendaknya guru menggunakan beragam pendekatan pembelajaran, media pembelajaran, dan sumber belajar pada pembelajaran membaca 
dan menulis permulaan. Guru hendaknya menjelaskan materi pelajaran kepada siswa secara maksimal agar tidak terjadi kesalahan konsep dan membantu pemahaman siswa secara menyel

3.Pada tahap evaluasi hendaknya dilakukan guru untuk setiap proses pembelajaran, khususnya untuk penilaian hasil belajar ranah kognitf, afektif serta pisikomotorik harus mengikuti permendikbud nomor 4 tahun 2018 tentang penilaian hasil belajar. Hal itu karena dalam kurikulum terbaru yang di keluarkan yaitu peraturan pemerintah mengutamakan ranah kognitif, afektif, pisikomotorik.

\section{Referensi}

Abdullah, Ramli, 2012. Pembelajaran Berbasis Sumber Belajar. (Jurnal Ilmiah Didaktika Fakultas Tarbiya IAIN Ar-Raniry)

Abdurahman, M. 2003. Pendidikan bagi anak berkesulitan belajar. Jakarta Renika Cipta.

Aqib, Zainal. 2010. Profesionalisme Guru dalam Pembelajaran. Surabaya: Insan Cendikia

Artena, Suarmei. 2014. Pengaruh Metode SAS Berbantuan Media Kartu Huruf Terhadap Keterampilan Membaca dan Menulis Siswa Kelas II (Jurnal Mimbar PGSD Universitas Pendidikan Ganesha Jurusan PGSD)

Bogdan R \& Biklen S.K. 2005. Qualitative Research endukation, An Introduction

Darmawati. 2013. Penilaian Angka Kredit Guru.Jakarta: Bumi aksara

Dubin. 2009. Metode Khusus Pengajaran Bahsa Indonesia di Sekolah Dasar. Jakarta : Bumi aksara

Dwicahyono, Daryanto. 2014. Pengembangan Perangkat Pembelajaran. Yogyakarta: Gava Media

Ekowati. 2008. Strategi pembelajaran menulis. Sebelas Maret. University Press. Surakarta.

Hasanudin, Cahyo, Tarigan. 2016. Pembelajaran Membaca Permulaa dengan Mengunakan Media Aplikasi Bamboomedia Bmgames Apps Pintar Membaca Sebagai Upaya Pembentukan Karakter Siswa SD Menghadapi MEA. (Jurnal Pedagogia Fakultas Pendidikan Bashasa dan Seni, IKIP PGRI Bojonegoro).

Hasnudin, Cahyo. Dkk. 2017. Peningkatan Motivasi Keterampilan Membaca Permulaan Siswa Kelas I Melalui media Aplikasi Bamboomedia Bmgames Apps. (Jurnal Pendidikan IKIP PGRI Bojonegoro).

Herman J. Waluyo. 2006. Pengantar Filsafat Umum. Salatiga: Widya Sari Press

Mulyasa, E. 2008.Kurikulum Tingkat Satuan Pendidikan. Bandung: Remaja Rosdakarya. 
Khairani. 2013. Pisikologi Belajar. 2009.Standar Kompetensi dan Sertifikasi Guru. Yogyakarta : Aswaja Persindo.

Kurniastuti, Irine. 2016. Mengenal Kesukaran Belajar Membaca Menulis Awal Siswa Sekolah Dasar Dan Metode Montessori Sebagai Alternatif Pengajarannya. (Jurnal Pendidikan FKIP, Universitas Santa Dharma).

Kurniasih, Imas. 2014. Pendidikan Anak Usia Dini. Jakarta. Edukasia

Kusuma, Dewi. 2014. Penggunaaan Metode Setruktur Analitik Sentetik(SAS) Untuk Meningkatkan Kemampuan Membaca Menulis Permulaan Pada Siswa Kelas I (Jurnal Pendidikan FIP Universitas Pendidikan Ganesha Singaraja Indonesia).

Maulana, Syafrina, 2013. Efektifitas Metode VAKT untuk Meningkatkan Kemampuan Menulis Permulaan Bagi Anak Kesulitan Belajar. (Jurnal Pendidikan Luar Biasa, FIP UNP).

Mukhtar. 2013. Metode Penelitian Deskriptif Kualitatif. Jakarta: GP Press Group. Bandung: Remaja Rosdakarya

Mulyati, Yeti. 2014. Pembelajaran Membaca dan Menulis Permualaan. (Bandung UPI).

Nasution. 2011. Metode Research (Penelitian Ilmiah). Jakarta: Bumi Aksara.

Nurseto, Tejo. 2011. Membuat Media Pembelajaran Yang Menarik. (Jurnal Fakultas Ekonomi Universitas Negeri Yogyakarta).

Parjiati. 2012. Pendekatan Terpadu dalam Pembelajaran Bahasa Indonesia untuk Meningkatkan Kemapuan Menulis. (Jurnal).

Peraturan Mentri Pendidikan dan Kebudyaan Republik Indonesia Nomor 4 Tahun 2018. Penilaian Hasil Belajar Oleh Pemerintah.

Rahman dan Amri. 2013. Pengembangan Sistem Pembelajaran. Jakarta: Prestasi Pustakakarya.

Rusman. 2011. Model-Model Pembelajaran Mengembangkan Profesionalisme Guru. Jakarta: Rajawali Pers. Group.

Sedarmayanti. Hidayat, Syarifudin. 2011. Metodelogi Penelitian. 2014. Model-Model Bandung: Mandar Maju.

Ruslan, Rosady. 2010. Metode Penelitian Public Relations dan Komunikasi. Jakarta: Rajawali Pers

Kemendikbud. 2012. Pembelajaran Membaca dan Menulis di kelas rendah (Modul Bahasa Indonesia 5). Jakarta : BPSDMPK dan PMP.

Rina Iriani. 2011. Penerapan Model Tutor Sebaya dalam Membaca Permulaan Pelajaran Bahasa Indonesia. (Jurnal). 
Rusman. 2011. Model-model Pembelajaran. Jakarta: Rajawali Pers

Rusyana, Yus,.2004. Memperlakukan Sastra Bahasa Indonesiadan Sastra Bahasa Daerah Sebagai Sastra Milik Nasional, Makalah disajikan Pertemuan Ilmiah Nasional HISKI. Solo, 2-4 Oktober 2004.

Saparahahuaningsih. Sri. 2014 Metodelogi Pengembangan Anak Usia Dini (Modul).

Sanjaya, Wina. 2014. Perencanaan dan desain sistem pembelajaran. Jakarta Kencana Prenada Media

Somadayo, Samsu. 2011. Strategi dan Teknik Pembelajaran Membaca. Yogyakarta: Graha Ilmu.

Sri Harini, Ekowati. 2008. Strategi Pembelajarn Menulis Pada Mahasiswa Jurusan Bahasa Prancis Pemula Fakultas Bahasa dan Seni Universitas Negeri Jakarta, Jurnal Bahasa, Sastra, dan Pengajarannya. Surakarta: UNJ Press.

Sugiyono. 2012. Metode Penelitian Pendidikan. Bandung: Alfabeta.

Sukmadinata. 2005. Metode Penelitian Pendidikan. Bandung: Remaja Rosdakarya.

Sukmadinata, Nana Syaodih 2005. Landasan Psikologi Proses Pendidikan, Bandung: Rosdakarya.

Suryosubroto. 2009. Proses Belajar Mengajar di Sekolah. Jakarta: Rineka Cipta

Susanto. 2014. Teori Belajar dan Pembelajaran. Jakarta: Kencana.

Widoyoko. 2012. Evaluasi Program Pembelajaran (Jurnal Pendidikan Intrucional program evalution)

Winarni, Endang Widi. 2011. Penelitian Pendidikan. Bengkulu: Unit Penerbitan FKIP Universitas Bengkulu 